\title{
C-Met Inhibitor JNJ-38877605
}

National Cancer Institute

\section{Source}

National Cancer Institute. c-Met Inhibitor/N1-38877605. NCI Thesaurus. Code C77893.

An orally bioavailable, small-molecule receptor tyrosine kinase inhibitor with potential antineoplastic activity. c-Met inhibitor JNJ-38877605 selectively inhibits c-Met, a receptor tyrosine kinase (RTK) involved in cancer cell survival and invasiveness, and tumor angiogenesis. c-Met is also known as hepatocyte growth factor receptor (HGFR). 